\title{
Developing a Financial Stress Index for Pakistan
}

\author{
Haleema Sadia ${ }^{1}$, Arshad Ali Bhatti², Eatzaz Ahmad ${ }^{3}$
}

\begin{abstract}
This paper develops a financial stress index for the Pakistan economy covering the post-reform period. We use time series data for the period 1993M1-2016M12 and employ principal component analysis to aggregate various components of financial markets, real economic activity, and political risk in a single financial stress index. The computed index successfully explains the known periods of financial stress in Pakistan. It stresses upon the political and economic risks as important contributors of financial stress along with financial market factors. This composite index assesses the stability of the financial system, which is a public policy concern in most emerging economies. Thus, we believe that it can serve as an important benchmark to describe the systemic risk in the financial system.
\end{abstract}

Keywords: Financial market risk, economic risk, political risk, FSI for Pakistan, PCA.

JEL Classification: G00, G01, G18, G28, E44

\section{Introduction}

The global financial crisis of 2007-2008 adversely affected the stability of financial systems in both developed and developing countries. Unprecedented high levels of financial stress raised a debate on how to measure system-wide risk that could serve as a yardstick for the assessment of health of a financial system. According to the Systemic Risk Center (hereafter SRC) located at the London School of Economics, systemic financial risk is defined as the collapse of the entire financial system. This risk is endogenous to the financial system and is amplified through inter-linkages between various segments of financial system, such as banking, equity, debt and currency markets.

Analyzing financial stress in the context of Pakistan economy is significant as

1 PhD Scholar and Assistant Professor, Department of Economics, International Islamic University, Islamabad, Pakistan. Email: haleema.sadia@iiu.edu.pk

2 Assistant Professor, School of Economics, IIIE, International Islamic University, Islamabad, Pakistan.

Email: arshad_bhatti@iiu.edu.pk

3 Professor, Department of Economics, Quaid-i-Azam University, Islamabad, Pakistan.

Email:eatzaz@qau.edu.pk

\section{ARTICLE HISTORY}

13 Feb, 2019 Submission Received

02 Apr, 2019 First Review

11 Sep, 2019 Second Review

06 Nov, 2019 Third Review

22 Nov, 2019 Accepted 
the country launched its financial reforms agenda in the 1990s (SBP, 2000) ${ }^{4}$. Prior to these reforms, the financial system was financially repressed, segmented, highly protected and state-controlled with the inherent problem of instability. Induction of foreign competition through privatization, financial liberalization and the lifting of capital and exchange controls enhanced the efficiency of the banking sector in particular, and of the financial markets in general. However, with increased financial globalization, the task of the central monitoring authority is made more complex in terms of minimizing the systemic risk through contagion and domino effects ${ }^{5}$ and curbing the environment of excessive risk-taking, besides its traditional role of price stability. In this context, a precise measure of financial stress can be a fruitful exercise; on one hand, it can serve as a risk assessment tool for the monetary authority, while on the other hand, it is an important tool for policymakers to assess the soundness of the financial system.

There exists a void between academic research and the conventional process of policymaking on this front. Policymakers merely focus on disciplining the behavior of investors and other market participants to ensure financial stability, while academic research establishes a link between political stability and the performance of various segments of the financial system (Ghufran, Awan, Khakwani, \& Qureshi, 2016). More recently, researchers highlighted a flaw in the existing process of macro-prudential policymaking that it ignores political risk as an essential component of systemic financial risk (Danielsson \& Macrae, 2016). Political leadership generally influences the regulatory authorities in the process of formulating and executing policies to monitor and manage the level of financial stress in the system. Thus, political risk is recognized as a non-economic driver of uncertainty in the financial markets (Dziawgo, 2013; Waszkiewicz, 2015, 2017). Likewise, existing research rarely includes the role of economic factors in the measurement of financial stress ${ }^{6}$. Further, this study incorporates the role of real sector fluctuations as measured by output gap in the construction of financial stress index (FSI hereafter) for Pakistan. The motivation to incorporate economic factors is derived from the understanding that real and financial cycles are inter-linked. Till date, none of the empirical studies have incorporated political and economic risks, besides financial risks, as explicit components of financial stress for the Pakistan economy as well as for the other economies. Most of the studies have focused on financial risk only (Mahmood \& Hussain, 2016 and Akbar \& Batool, 2015 for Pakistan; Illing \& Liu, 2006 for Canada; Sandahl, Holmfeldt, Ryden, \& Stromqvist,

4 A broader set of reforms were introduced for institutions, debt and monetary management, banking laws, exchange and payment, and capital markets.

5 Domino effect refers to the phenomenon where crashes in the local market may spread to regional markets or even global markets (Makrwat, Kole, Eु Dijk, 2009).

6 A few exceptions do exist, such as Cevik et al. (2013a) for Turkey; Dahalan et al. (2016) for Malaysia; and Cevik et al. (2013b) for emerging economies. 
2011 for Sweden; Cardarelli, Elekdag, \& Lall, 2011 for advanced countries; and Balakrishnan, Danninger, Elekdag, \& Tytell, 2011 for emerging economies). Few studies acknowledged the role of economic as well as financial factors (Cevik, Dibooglu, \& Kenc, 2013a for Turkey; Dahalan, Abdullah, \& Umar, 2016 for Malaysia; and Cevik, Dibooglu, \& Kutan, 2013b for emerging economies). Thus, we believe that financial stress not only stems from the inter-linkages between various segments of financial markets (as mentioned by SRC) but also from the linkages between the financial and real sides of the economy as well as political uncertainty.

Against this background, this study aims to construct a composite FSI to assess the degree of financial stress in the context of an emerging economy like Pakistan. We account for three types of risk, i.e. financial, economic and political. In addition, we try to explore the sources of financial instability by analyzing the stress contribution of various components of composite index. Financial and economic risks hinder the ability of the government to safeguard financial stability, whereas political risks deal with the willingness to execute optimal policies for the smooth functioning of the financial system. The motivation to build a FSI for Pakistan can be justified on various grounds. First, standalone indicators for various segments of the financial system can move in opposite directions, making it difficult to precisely assess systemic risk. FSI for Pakistan that encompasses financial, economic, and political risk, thus enabling policymakers to correctly assess the level of systemic financial risk. Second, FSI can help us study the sources of financial stress in the financial markets. Next, composite index of contemporaneous nature can serve to assess the degree of systemic risk in crisis as well as tranquil periods, enabling the central bank to formulate unconventional policy responses in the wake of stressful episodes (Balakrishnan et al. 2011). Lastly, measuring financial stress is important not only as a risk assessment tool in the financial system but also as a public policy concern (Aftab, 2013).

\section{Literature Review}

FSI measures the systemic risk prevailing in the financial markets that cannot be captured through individual indices for the various segments of financial market. Several studies constructed indices for groups of emerging economies. For example, Balakrishnan et al. (2011) constructed FSIs for 25 emerging economies and studied the transmission of financial stress from advanced to emerging economies by distinguishing between stressful and calm periods. They found transmission is more intense during stressful periods. Financial stress in advanced countries contributes $70 \%$ towards the financial stress in emerging economies when the advanced economies are in stress. Even during periods of calm, stress transmission decreases by $30 \%$ if emerging economies experience current account and fiscal surpluses and higher 
reserve accumulation. They found financial linkages are a more important source of stress transmission than trade linkages.

Extending the work on the transmission of stress, Park and Mercado (2014) constructed FSIs for 25 emerging economies and evaluated the transmission of stress within emerging economies. They used quarterly data for the period 1992-2012 and considered banking, foreign exchange, equity, and debt market indicators for the construction of FSIs. Their findings show that financial stress in an emerging economy can be transmitted to other emerging economies and that non-regional transmission is as important as the regional one for all except Emerging Asia. Likewise, Poonpatpibul, Tan, Liu Xinyi, and Cho (2018) developed country-specific as well as regional FSIs for 8 emerging economies, including Korea, Japan, China and the ASEAN region. This study exploited high frequency daily data for 9 financial indicators. These indicators covered five financial markets - stock, corporate debt, sovereign debt, interbank and money, and the foreign exchange market. They used Principal Component Analysis (hereafter PCA) to construct individual country FSIs. To identify the sources of stress, they adopted the constrained regression method. Country indices were aggregated using GDP size and the importance of financial linkages as weights. Their findings suggest that FSIs predict well the global, regional, as well as country-specific episodes. The regression method shows that the global financial crises contributed to overall financial stress for all countries whereas the Euro area crises affected the ASEAN region. They further concluded that global common factors, financial linkages and more trade with a systemic country amplified regional FSI. Also, the regional stock and currency markets remained sensitive to development in China's financial sector relative to shocks originating from the US.

A few studies acknowledge the role of economic factors in the measurement of FSI. For example, Cevik et al. (2013a) modified the index proposed by Balakrishnan et al. (2011) by incorporating external debt in the construction of an FSI for Turkey for the period 1997-2010. External debt, as an economic factor, hinders financial stability through debt overhang effect. ${ }^{7}$ A similar study was done by Dahalan et al. (2016) to construct an FSI for the Malaysian economy by considering external debt as an element of financial stress. Cevik et al. (2013b) measured financial stress for five emerging economies by acknowledging both the economic and financial components. They included six components, namely banking sector fragility, time varying stock market volatility, sovereign debt spreads, exchange market pressure index, and trade credit in the analysis. Their results from PCA indicate that respective FSIs explain 34-58 percent of the total variation in six variables.

7 Debt overhang refers to a situation when existing stock of debt in a country is too large that government cannot take new debt to finance future projects. It further lowers the incentives to invest, lowers public investment, accelerates liabilities and impairs access to credit from international markets. 
Literature on the measurement of financial stress in Pakistan is very limited. Mahmood and Hussain (2016) computed an FSI for Pakistan by considering banking, stock market, and sovereign risk components. However, their study employed an ad-hoc definition for the identification of financial stress. In a similar study, Akbar and Batool (2015) concluded that banking and stock market volatilities are major contributors to FSI for Pakistan. They further inferred that higher financial stress discourages economic activity. None of these studies, however, considered the role of economic and political risks in the construction of an FSI for Pakistan.

Overall, the existing literature highlights various unsettled issues. First, the role of political risk is not considered as yet as a component of FSI; this consideration may enhance the predictive power of the composite index (Dziawgo, 2013; Danielsson \& Macrae, 2016; Waszkiewicz, 2015, 2017). Second, existing studies consider only crisis stemming from currency, banking and debt markets with little attention given to system-wide events and securities market stress (Balakrishnan et al. 2011; Laeven \& Valencia, 2013). Finally, the role of credit stress is not incorporated in the construction of the FSI except in few studies (Cevik et al. 2013a and Dahalan et al. 2016). This study considers the above issues and provides a comprehensive account of an FSI for Pakistan.

\section{Concept and Components of FSI for Pakistan}

Financial stress has no precise definition as it is a broad concept. Hakkio and Keeton (2009) elaborate financial stress as a state of increased uncertainty about the fundamental value of the asset and behavior of investors, increased asymmetry of information, and the reluctance to hold risky and illiquid assets. Balakrishnan et al. (2011) define periods of financial stress in which a financial system fails to play its intermediary role.

Besides financial risk, the role of political risk is also recognized as an important source of disruptions in financial market. In fact, political risk is more dangerous than financial and economic risk with a realization that increasing intervention of the government into the economy ends up limiting the scope and efficacy of economic regulations (Dziawgo, 2013). Mei and Guo (2004) conclude that political risk contributes more significantly than financial contagion towards financial crisis in emerging markets. Financial markets are negatively affected by politics that tend to create problems in economic system, such as poor management of public finance, lack of vision to resolve the problem of debt, political pressures to formulate un-optimal policies 
for vested interests ${ }^{8}$ and the manipulation of corporate taxes 9 (Dziawgo, 2013; Danielsson \& Macrae, 2016). These problems provide a theoretical ground for exploring the role of political risk as a potential threat for the stability of the financial system.

The FSI for Pakistan accounts for three types of risks to the economy, i.e. financial, economic and political. This study considers five components of financial risk based on four financial markets, namely banking, currency, debt and equity markets. Economic risk is captured through the output gap, whereas political risk is assessed through qualitative characteristics based on the methodology of International Country Risk Guide (hereafter ICRG). These components are explained below.

\subsection{Stock market risk}

A sharp decline in the stock price index signals a crisis in stock market and increased stress related to the securities market. Such a decline represents expected losses or higher risk or increased uncertainty about the future returns of the firms. This study measures stock market volatility using the GARCH model as suggested by Bollerslev, Chou, and Kroner (1992). The most popular specification of GARCH model, that is GARCH $(1,1)$, is given as under:

$$
\sigma_{t}^{2}=\alpha+\varphi_{1} \varepsilon_{t-1}^{2}+\varphi_{2} \sigma_{t-1}^{2}
$$

where $\sigma^{2}$ represents the conditional variance and $\varepsilon$ refers to the error term in conditional mean equation given below:

$$
s_{t}=\alpha_{i, t}+\beta s_{t-1}+\varepsilon_{t}
$$

where $s_{t}$ indicates daily stock market returns at time $t$, while monthly average of the conditional variance is taken to trace out the monthly volatility. ${ }^{10}$ Daily stock returns are computed as the log first difference of the closing stock price index of consecutive trading days.

\subsection{Banking sector risk}

Riskiness of the banking sector is an essential component of an FSI as many studies point out that a weak banking system was a decisive factor for the Asian financial

8 It is believed that the financial crisis of 2007-2008 began with a failure of the Federal Reserve to act against excessive mortgage loans issued as the Fed wanted to support the home ownership policy of the US Congress. Thus, macro-prudential regulations are clearly constrained by political decisions.

9 Tobin tax on financial markets in G-20 and mineral tax in the Polish economy are examples of such activities.

10 A higher order GARCH model is estimated initially and then significance of lagged coefficients is used as a criterion for finalizing the order of the GARCH model. Further, we test the presence of ARCH effects in residuals by applying the ARCH LM test. 
crisis of 1997 (Turner, 2007). This study employs the Capital Asset Pricing Model (CAPM) to assess the riskiness of the banking sector, that is,

$$
\left(r_{t}-r_{f t}\right)=\alpha_{t}+\beta_{t}\left(s_{t}-r_{f t}\right)+u_{t}
$$

where, $r$ and s represent daily returns to the banking and stock market indices of Pakistan respectively at time $t$ and $u$ is an error term at time t. Returns are calculated by taking the log first difference of daily banking and stock market indices. We take period average over each month to convert daily returns into monthly. Risk free rate of return at time $t$ is denoted by $r_{\mathrm{ft}}$. It is measured by the 3-month Treasury bill rate. Excess returns (risk premium) for stock market are obtained by the difference between stock market return and risk-free rate of return. Similarly, risk premium for the banking sector is obtained as the difference between banking sector returns and the risk-free rate of return. If volatility coefficient of the banking sector, $\beta_{t}$, is greater than 1 , it will indicate that the volatility of the banking sector return is higher than that of the overall market return. Higher $\beta$ is an indication of greater stress in the banking sector and vice versa. High frequency (daily) data is considered to calculate risk in low frequency (monthly) data.

\subsection{Currency risk}

Depreciation of currency and a fall in foreign exchange reserves are often considered as indicators of a currency crisis, which is again an important component of financial stress. Devaluation of currencies leads to capital flights by hampering the confidence of consumers and investors, thereby raising financial stress. We measure currency risk through the exchange rate market pressure index (hereafter EMPI) introduced by Girton and Roper (1977) and empirically applied by Eichengreen, Rose, and Wyplosz (1996) and Burnside, Fichenbaum, and Rebelo (2004). The idea is how the central bank responds to excess demands for foreign currency. There are two policy options: first is to allow the depreciation of the domestic currency, while second is to accommodate the excess demand for the foreign currency through the sale of foreign exchange reserves. Accumulated effect of depreciation of currencies and falling reserves captured through EMPI is defined as:

$$
E M P I_{t}=\frac{\left(\Delta e_{t}-\mu_{\Delta e}\right)}{\sigma_{\Delta e}}-\frac{\left(\Delta R E S_{t}-\mu_{\Delta R E S}\right)}{\sigma_{\Delta R E S}}
$$

where $\Delta \mathrm{e}_{\mathrm{t}}$ is percentage change in the exchange rate at time t; $\Delta \mathrm{RES}$ is percentage change in foreign exchange reserves at time $t ; \mu$ and $\sigma$ represent mean and standard deviation of the respective variables. 


\subsection{Sovereign risk}

Sovereign risk refers to the situation wherein a nation is unable to service its foreign debt liabilities. Spread between the yields of risky and a risk-free bond is a widely-used indicator of sovereign risk (Sandahl et al., 2011; Balakrishnan et al., 2011; Lo Duca \& Peltonen, 2011). In the present context, it is measured as the yield differential between long-run (10 years) Pakistani bond and long-term US Treasuries. US bond is considered to be risk free as these are guaranteed by the US government who is able to print dollars. Since bond markets are well developed and stable, it is unlikely that bonds issued by the US government will default. The higher bond spread indicates a higher risk of default for Pakistan as compared to the USA. A bullish stance in Pakistan's bond market makes Pakistan's bond riskier as compared to the US bond. Investors demand higher risk premium which lowers the prices of bonds. Thus, higher spread and lower prices are further factored into periods of higher financial stress.

\subsection{Credit stress}

Excessive supply of credit during periods of boom is followed by credit constraints in times of financial crisis. Lower credit raises credit stress, which is an important element of financial stress (Misina \& Tkacz, 2009). We measure credit stress through the growth in claims on private sector (Cevik et al. 2013a).

\subsection{Output gap}

A positive output gap indicates overheating of the real economy, as characterized by a credit boom and a rise in asset prices. Financial boom is associated with unsustainable high levels of actual output above potential output. Such developments in the financial sector are coupled with currency appreciation and lower inflation, as it happened during the global financial crises of 2007. The real economy starts melting with credit busts followed by credit booms. This causes financial instability, which is translated into financial stress (Borio, Disyatat, \& Juselius, 2013).

\subsection{Political risk}

Political risk refers to "how political decisions in an economy stabilize or destabilize the free market" (Titman, Kewon, \& Martin, 2011). It stems from the operations of the government and is recognized as a driving factor for stock prices in both developed and emerging economies (Diamonte, Liew, \& Stevens, 1996). It is measured by various qualitative indicators, as taken from the ICRG designed by the Political Risk Services group (hereafter PRS). 


\section{Data and Construction of an FSI for Pakistan}

We construct a monthly FSI of Pakistan for the period 1993-M1 to 2016-M12. The choice of the sample period is based on the criterion that Pakistan economy underwent financial reforms in the early 1990s. We aim to assess, on one hand, how these reforms improved the efficiency of the financial system while, on the other hand, what are the potential perils associated with financial globalization. Daily data for the banking sector index and the overall stock market index and monthly data on long-term government bond yield with 10 years' maturity are taken from Thomson Reuters DataStream. We extract monthly data on risk-free rate of return, claims on private credit, foreign exchange rate and international reserves from the International Financial Statistics (hereafter IFS). To find sovereign spread, daily data on US long-term treasury bond with a maturity of 10 years are collected from the website of Federal Reserve Bank. Since monthly national income accounts are not frequently available, the monthly data on industrial production, measured at constant 2010 US $\$$ are used as a proxy for real output. Data on industrial production are taken from the Global Economic Monitor database published by the World Bank. Output gap is estimated by employing logarithmic quadratic trend method (hereafter QTM). This method relaxes the assumption of a constant growth rate of GDP and separates the structural and cyclical components by modeling the observed behavior. Thus, the estimates become more realistic (Cerra \& Saxena, 2000). Monthly seasonal dummies are also included in the QTM to factor out seasonality from the output gap.

Political risk index (hereafter PRI) is constructed by summing up 12 political and social attributes by using annual ICRG data. ICRG methodology assigns rating points to these attributes. Index is scaled between 0 and 100. A higher value indicates lower risk and vice versa. Stock market risk, banking sector beta, US long-term treasury bond yield are converted into monthly frequency by taking period averages. PRI is converted into monthly frequency by applying the following formula:

$$
P R I_{i, t}=P R I_{t-1} *\left[\frac{P R I_{t}}{P R I_{t-1}}\right]^{\wedge\left(\frac{i}{12}\right)} ; i=1,2, \ldots, 12
$$

where, $\mathrm{PRI}_{\mathrm{i}, \mathrm{t}}$ is the political risk index in the $\mathrm{i}^{\mathrm{t}}$ month of year $\mathrm{t}$; PRI is the political risk index in the year $t$; $\mathrm{PRI}_{\mathrm{t}-1}$ is the political risk index in the year $\mathrm{t}-1$.

All the components of financial stress are standardized before aggregation. We apply PCA method for aggregating stock market volatility, banking beta, EMPI, yield differential, growth in private credit, output gap and political risk index into a single composite index. PCA relies on a few linear combinations of original data on a relatively large number of mutually correlated variables representing similar attributes to capture the variations in the observed data. The first principal component captures 
the maximum proportion of variation of original variables. The second component, which is orthogonal to the first component, accounts for maximum of the remaining variation, and so on. We try to extract the highest possible variation in the observed data by using the smallest possible linear combinations.

\section{Results and Analysis}

A key issue in the construction of an index based on PCA is to decide the number of components retained for the construction of index. Earlier literature suggests that the cumulative proportion of the explained variation should be at least 50-60 percent of the available information (Park \& Mercado, 2014). The results of the PCA are reported in Table 1 . Since the first component only explains 22 percent of the variation, we derive the FSI from each of the first three components that cumulatively explain 55 percent of the total variation. Non-standardized average of the three indices provides a composite FSI for Pakistan.

Once the composite index is computed, the next step is to evaluate the stressful periods to observe whether the peaks in the FSI for Pakistan are consistent with the known periods of stress. Figure 1 presents the computed FSI for Pakistan. As the figure shows, the first stress episode was observed in 1993 when privatization of the banking sector, abolishing of the system of credit ceiling, and directed credits raised the volatility in the banking sector. The banking industry was characterized by foreign competition, while regulatory frameworks were still not mature enough to mitigate the risks. The second episode of stress appeared in the wake of the general elections, which raised political uncertainties and further contributed towards financial stress in the latter half of the year. Moreover, the expansionary monetary policy and easy credit conditions resulted in a credit boom and overheating of the real economy. Thus, an overheated economy raised the economic risk. Financial stress subsided in subsequent years as non-performing loans decreased until 1996 and the banking sector reforms got momentum (SBP: Financial Stability Review, 1999-2000). This episode confirms our claim that, besides the risks originating from financial system, economic and political risks do matter if we consider inter-linkages between financial and real markets.

The third stressful episode experienced by the Pakistan economy emerged in September 1995 when exports followed a declining trend coupled with a rising import bill during the first half of fiscal year. Besides that, worker's remittances, a major source of foreign exchange (hereafter FOREX) earnings, declined by 18.8 percent in first 9 months of fiscal year 1995-1996. Thus, exchange rate depreciated by 8 percent in September 1995 to avoid balance of payment problems. Currency risk, and hence the FSI for Pakistan, increased as a cumulative effect of falling reserves and depreciation 
Table 1: Results for Principal Component Analysis

\begin{tabular}{|c|c|c|}
\hline Component & Eigenvalues & Proportion \\
\hline Component 1 & 1.57 & 0.2250 \\
\hline Component 2 & 1.28 & 0.1835 \\
\hline Component 3 & 1.02 & 0.1460 \\
\hline Component 4 & 0.97 & 0.1388 \\
\hline Component 5 & 0.88 & 0.1265 \\
\hline Component 6 & 0.77 & 0.1103 \\
\hline Component 7 & 0.48 & 0.0699 \\
\hline
\end{tabular}

in the Pakistan Rupee (Pakistan Economic Survey, 1995-1996).

The next stressful period appeared in October 1997 when stock market plummeted, and Pakistan Rupee depreciated by 8 percent as a contagion effect of the Asian financial crisis. The currency depreciation escalated the currency crisis that raised the FSI for Pakistan. The effect was transitory as the country fairly sailed through the crisis and averted a balance of payment crisis through debt re-scheduling and support from international lending agencies, but the problems persisted in the domestic front (Pakistan Economic Survey, 1999). Financial stress further intensified in a fifth episode of stress as economic sanctions, because of the nuclear tests in May 1998, jeopardized Pakistan's financial stability. Subsequently, the freezing of foreign currency accounts in July 1998, poor law and order conditions, inflationary pressures, dwindling FOREX reserves and capital flight deepened the financial stress. Debt became more difficult to manage and the widened bond spread raised the sovereign risk. Thus, currency risk, political risk, and stock market volatility contributed to higher level of financial stress in the fifth stressful period.

The country moved towards a unified exchange rate after the economic sanctions. The next spike in the FSI occurred in December 1999 when foreign currency reserves reached a record low, which exacerbated a currency risk and, hence financial stress. Debt as a percentage of GDP continued to increase throughout the 1990s, and touched 100 percent in 2001 before it halted. The next four years were marked as tranquil periods where the financial system undertook structural reforms. This period was characterized by a resilient banking sector with excess credit, a well performing stock market and sound macroeconomic conditions (IMF, 2004). The share of private assets in the financial system and banking sector rose substantially during first two years of the 2000s. Besides, supervision of the financial system improved with coordinated efforts of the Securities and Exchange Commission (hereafter 


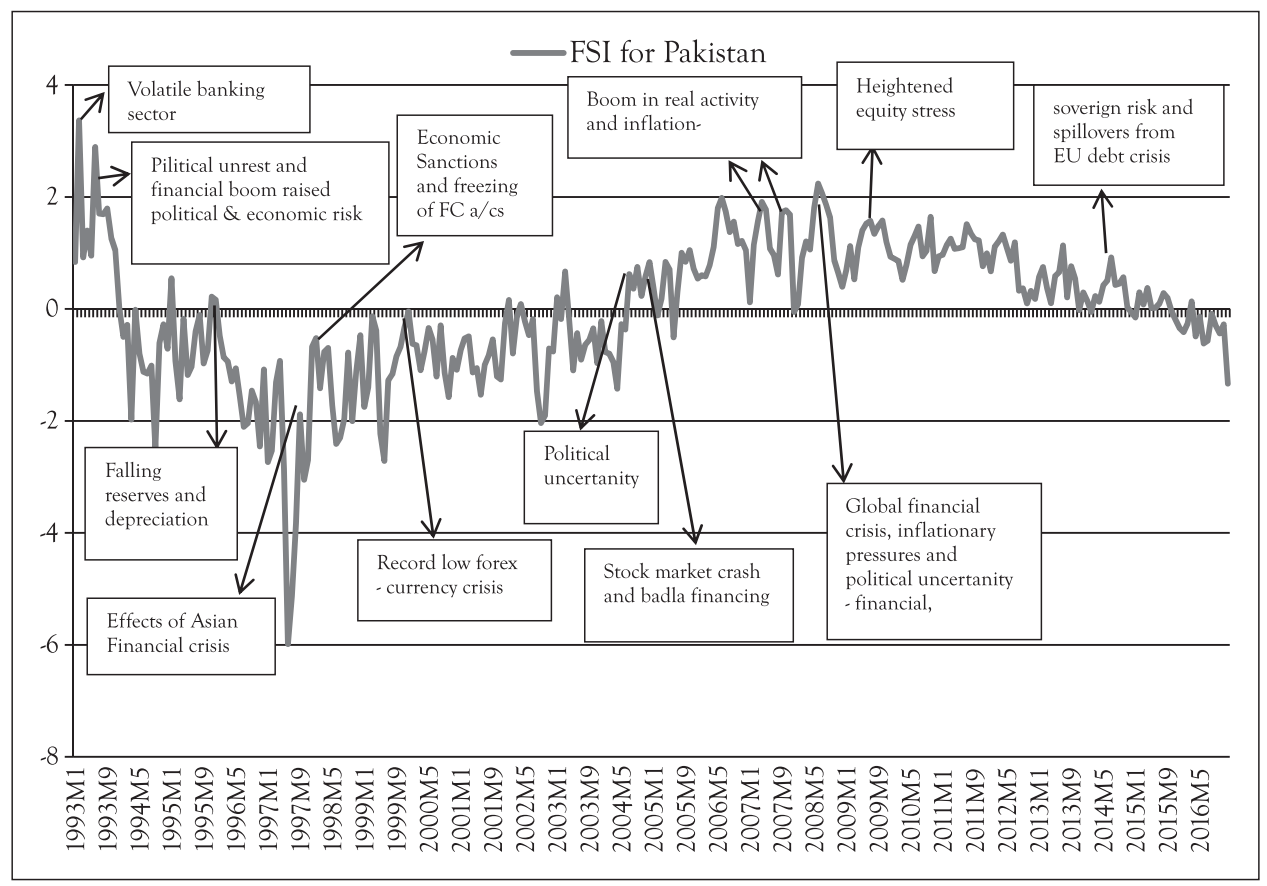

Figure 1: Financial Stress Index for Pakistan

SECP) and the State Bank of Pakistan (hereafter SBP). The economy also followed a path of debt sustainability with the implementation of prudent debt management in 2000-2003. However, speculative trading made the financial system vulnerable to systemic risk once again. The stability of the financial system was also endangered by the credit boom and an unprecedented high level of the stock market index that could be attributed to strong fundamentals. These favorable developments promoted financial stability (WB: Financial Sector Assessment, 2000-2003).

The weaker economic fundamentals in the latter half of 2004 forced adjustments in the exchange rate to cope with balance of payment and inflationary pressures. A seventh stressful episode surfaced with a sudden fall in the stock market index in March 2005 in response to speculative trading, as small investors followed animal spirits. The exchange rate was manipulated once again by imposing a freeze ${ }^{11}$ and introducing badla ${ }^{12}$ financing. Pakistan faced higher levels of financial stress in the next two years despite sound economic growth, a resilient banking system, low currency risk associated with stable exchange rate, rising FOREX reserves, and low credit stress.

11 Freeze refers to an interruption in trading activity when trading violated the order set by the exchange commission.

12 Badla is a collateralized short-term lending made to investors who lack funds and want to buy shares. The financier provides a loan to buy those share at the premium determined by the market. This informal source of financing is frequently used in the Pakistan Stock Exchange. 
Higher stress was attributed to higher inflation, a rise in demand at domestic front, and a spike in global oil prices. It undermined macroeconomic stability and posed a serious problem of rising economic risk, which translated into higher financial stress (Pakistan Economic Survey, 2007; SBP: Financial Stability Review, 2007).

The problems inherent in domestic and international markets explain the eighth spike in financial stress in 2008. On the domestic front, political uncertainties increased as the judiciary crisis surfaced on the political landscape of the country. It intensified the problems associated with the stubborn inflationary trends already prevailing in the country. This confirms our claim that political and economic risks are also not important in raising financial stress besides the risks generated from the financial markets. At the global level, the volatility of leading stock markets, including Pakistan's, increased considerably. However, the Pakistani stock market was insulated from a steep decline because of the ongoing reforms. Another striking development was the global upsurge in banking sector risk. But Pakistan's banking sector stayed resilient except for the failure of a few small banks to meet their obligations. Credit was concentrated with a few large banks and the financial system was not so deeply integrated with the global financial system. The recession in the advanced economies brought second-round effects from the financial crisis. Such feedbacks appeared through trade linkages, squeezed inflows of capital, dismal performance of the real sector, and structural imbalances. These problems made the country highly vulnerable to bankruptcy risks. This situation aggravated further with the soaring debt and balance of payment crisis. Consequently, the financial stress rose to unprecedented levels (Pakistan Economic Survey, 2009; SBP: Financial Stability Review, 2009).

Financial stress was further intensified in 2009 when the stock market plunged to a historic low. This marked the ninth episode of the FSI for Pakistan. It aggravated further as inflationary pressures persisted in the economy. The economy enjoyed surpluses in the balance of payment that cushioned it against the currency risk. Currency risk remained very low until 2011, however financial surplus was financed through debt flows rather than increased investments. The problems of the twin deficits in 2012 depicted little stress. Depleting reserves and liquidity constraints, besides energy crises and poor law and order situation, raised the currency risk. Systemic risk appeared once again in 2014 when the sovereign spread widened further. As a trading partner of Europe, the euro-debt crisis reduced the demand for Pakistan's exports that offset the favorable effects of falling oil prices. The stress in the financial markets remained substantially low during 2015 and 2016 as the country achieved macroeconomic stability despite the weaker outlook of the world economy as characterized by global political uncertainties, growth slowdown in the leading emerging markets and the falling oil prices (SBP: Financial Stability Review, 2015, 2016). Debt remained high 
in 2015-2016, but it was financed through excessive reserves.

Overall, our analysis suggests that the stock market and banking sectors were the major contributors towards FSI for Pakistan in the 1990s. Though these findings are in line with Akbar and Batool (2015), they also validate the claim that economic and political factors are equally important in escalating financial stress in Pakistan besides financial risk.

To look more deeply into the stress contribution from the various components, we plot components of financial stress in Figure 2. Figure 2a suggests stock market volatility contributed significantly to raise the systemic risk in the 1990s. Political instability, contagion effects from the Asian crisis and herd behavior dominated the market in 1990s. This is in conformity to Ghufran et al. (2016). Volatility in the stock prices reduced in 2001-2003 as the SECP initiated reforms to improve the management and operational efficiency of the market. Circuit breakers were introduced to curb excessive volatility in the stock market. The global financial crisis raised the volatility once again, but the effect sustained for a short time and the volatility of the stock market remained low due to regulations and strict supervision. Figure $2 \mathrm{~b}$ indicates banking risk stayed high in the same period owing to the lack of risk-mitigating tools, high levels of nonperforming loans and the credit boom. However, banking sector risk mitigated between 2000-2010 in terms of its size, structure, capital adequacy ratio and profitability. The risks associated with the public-owned banks halted as the reforms in the banking sector got momentum. The sector stayed highly resilient even in the aftermath of global financial crisis (SBP: Financial Stability Review, 2010).

As far as the foreign exchange market is concerned, the risks associated with the currency crisis can be analyzed for two periods. Prior to the 9/11 event in 2001, the economy suffered from high currency risk owing to exchange controls and speculative trends. As a financially integrated economy, the Asian financial crisis carried spillovers of currency crisis, as shown by higher levels of EMPI in Figure 2c. However, the establishment of the SECP in 1999 and the adoption of a market-based exchange rate system marginalized the adverse spillovers from the Asian crisis. After the 9/11 event, the influx of foreign exchange reserves and self-fulfilling expectations restored trust in the Pakistan Rupee. Less intervention by the monetary authority in the foreign exchange market coupled with conditionalities from the IMF helped achieve stability in the foreign currency market, and a currency crisis became unlikely.

The debt profile of the country remained weak in the 1990s. Sovereign risk escalated as well owing to poor debt management. This trend halted in the 2000s when the country attained debt sustainability following better debt management and lower sovereign risk, as shown in Figure 2d. A higher level of non-performing loans, 

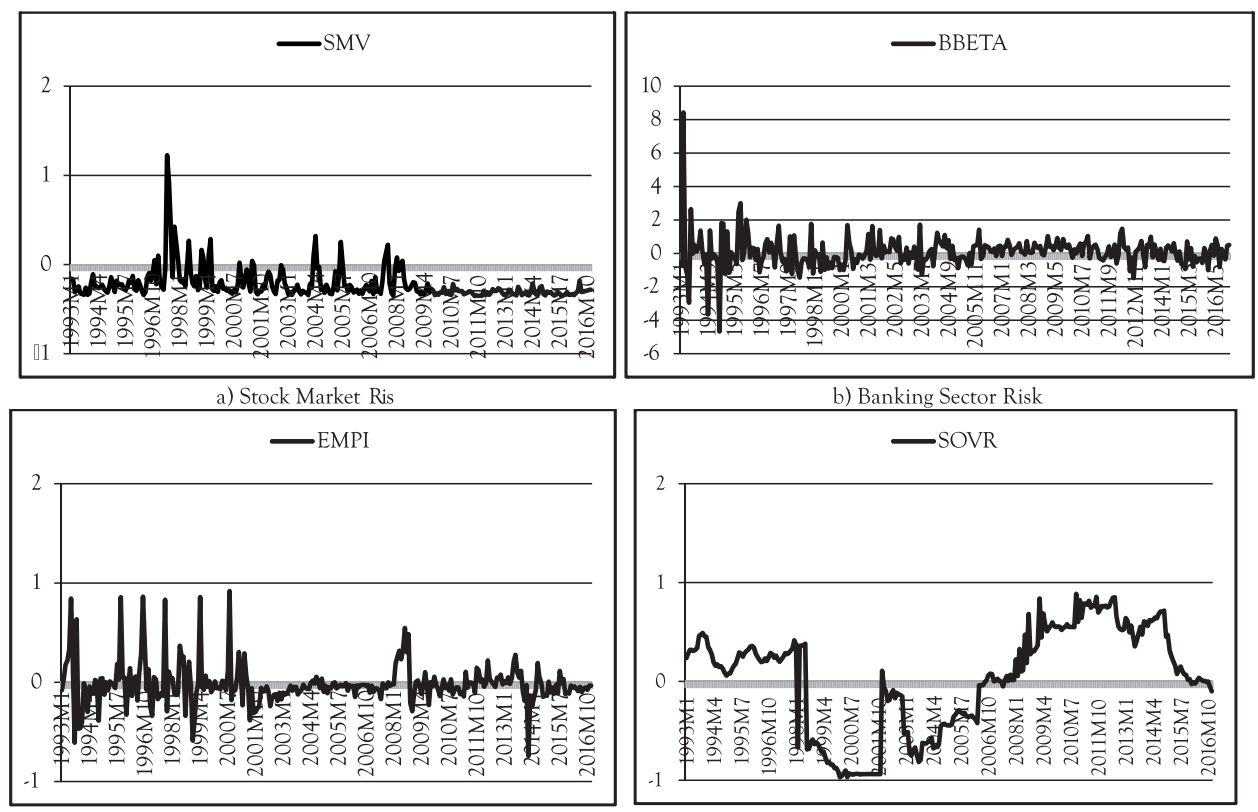

c) Currency Risk

d) Soverign Risk

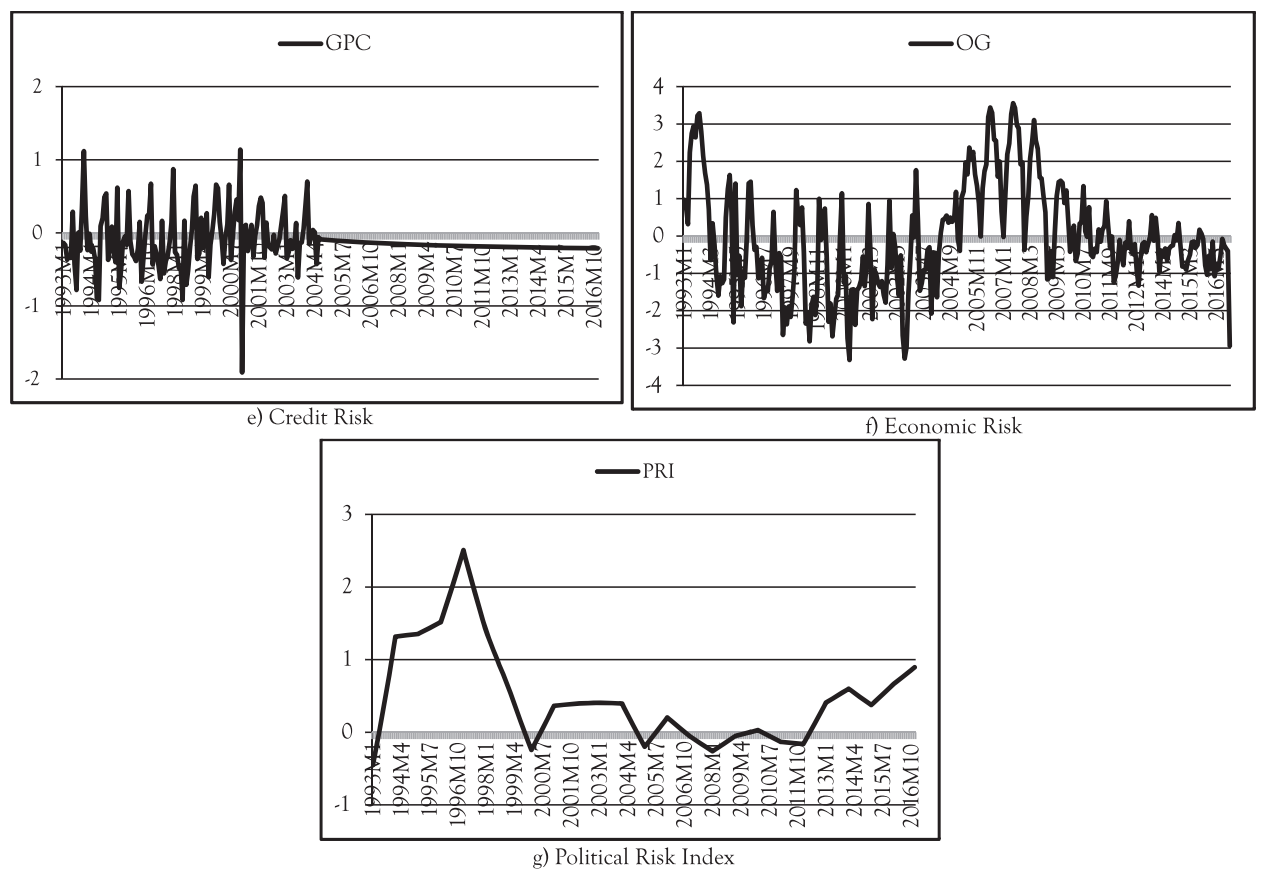

Figure 2: Contributions of Various Components in FSI for Pakistan

Note: SMV, BBETA, EMPI, SOVR, GPC, OG, and PRI refers to stock market volatility, banking sector beta, exchange rate market pressure index, sovereign risk, growth in private credit, output gap, and political risk index. 
directed credits and abolition of credit ceiling resulted in credit boom in the 1990s. Political stability and the continued assistance from abroad raised the credit rating of the country in 2005 and, hence, the lowered credit risk, as shown in Figure 2e. The credit boom resulted in an overheating of the real economy and raised the economic risk, as shown in Figure 2f.

Figure $2 \mathrm{~g}$ confirms that Pakistan faced higher political uncertainty in 1990s when the democratic governments could not complete their tenures and corruption scandals against the ruling party surfaced time and again. Later, the political risk subsided in the first decade of 2000s, but the problem has reoccurred in the recent years. It is interesting to note that the periods of political instability are those when the stock markets were characterized as highly unstable and banking risk remained substantial. Uncertainties in the stock market and persistent depreciation of rupee slowed down economic activity in the latter part of the 1990s. Thus, our claim that there exist inter-linkages between the financial market turmoil and political uncertainty is overwhelmingly confirmed.

\section{Conclusion and Policy Guidelines}

This study constructs an FSI for the Pakistan economy covering the post-reform period to enrich the risk assessment toolkit for policymakers. The constructed index captures almost all the known periods of financial stress quite successfully and highlights the stress contributions of various components as well. Our findings confirm the claim that, besides stress originating from the financial markets, economic and political risks also contribute significantly to higher level of financial stress in Pakistan. The following policy suggestions can be derived from this study for the monetary authority.

Monitoring of systemic risk requires macro-prudent financial regulations that directly evaluate the overall stability of financial system as a single macroeconomic unit. The current toolkit of prudent regulations simply focuses on micro-prudent regulations. Thus, the central bank may reform the supervision mechanism of the financial system by introducing macro-prudent regulations to mitigate systemic risk. The central bank can regularly conduct surveys to assess the perceptions of all the stakeholders regarding systemic risk. The recently launched Systemic Risk Survey is a step in the right direction. Such surveys must be conducted more regularly.

Further, the monetary authority needs to devise incentive schemes for mitigating risks for the highly risky banks. For example, tax exemptions for diversifying risk can help in curbing excessive risk practices of banks. Since economic and political risks interfere with the stability of the financial system, the democratic process should be strengthened with the hope that economic policies and political decisions are aligned 
to each other and the various economic policies can continue despite changes in the political leadership.

The central monetary authority can devise an early warning system in which forward looking stress testing techniques may help in proactively identifying system-wide stress. Such vulnerability exercises can also help them identify the upcoming risks and devise policy responses. Additionally, out of sample forecasts for financial stress indices, incorporating financial, economic, and political variables can help in formulating the policy responses optimally.

\section{References}

Aftab, N. (2013). Perspectives on systemic risk measurement. SBP Research Bulletin, 9(1), 113-128.

Akbar, A., \& Batool, I. (2015). A financial stress measure for Pakistan economy: Implications for real economic activity, Science Interntaional, 27(6) 6423-6430.

Balakrishnan, R., Danninger, S., Elekdag, S., \& Tytell, I. (2011). The transmission of financial stress from advanced to emerging economies. Emerging Markets Finance and Trade, 47(Sup2), 40-69.

Bollerslev, T., Chou, R., \& Kroner, K. F. (1992). ARCH modeling in finance: A review of the theory and empirical evidence. Journal of Econometrics, 52(1-2), 5-59.

Borio, C., Disyatat, P., \& Juselius, M. (2013). Rethinking potential output: Embedding information about the financial cycle. BIS Working Paper No.404.

Burnside, C., Fichenbaum, M., \& Rebelo, S. (2004). Government guarantees and self-fulfilling speculative attacks. Journal of Economic Theory, 119(1), 31-63.

Cardarelli , R., Elekdag , S., \& Lall , S. (2011). Financial stress and economic contractions. Journal of Financial Stability, 7(2), 78-97.

Cerra, L., \& Saxena, S. C. (2000). Alternative methods of estimating potential output and the output gap: An application to Sweden. IMF Working Paper No 59.

Cevik, E. I., Dibooglu, S., \& Kenc, T. (2013a). Measuring financial stress in Turkey. Journal of Policy Modeling, 35(2), 370-383.

Cevik, E. I., Dibooglu, S., \& Kutan, A. M. (2013b). Measuring financial stress in transition economies. Journnal of Financial Stability, 9(4), 597-611.

Dahalan, J., Abdullah, H. B., \& Uma, M. (2016). Measuring financial stress index for Malaysian economy. International Journal of Economics and Financial Issues, 6(3), 942-947.

Danielsson, J., \& Macrae, R. (2016). The fatal flaw in macropru: It ignores political risk. Available at: https:// voxeu.org/article/tmacroprus-fatal-flaw 
Diamonte, R. L., Liew J. M., \& Stevens R. C. (1996). Political risk in emerging and developed markets. Financial Analysts Journal, 52(3), 71-76.

Dziawgo, L. (2013). Political risk on the financial markets: The problem of adequate scientific assessment of business operations- The naivety of economists. Financial Internet Quarterly, 9(4), 39-47.

Eichengreen, B., Rose, A., \& Wyplosz, C. (1996). Contagious currency crises: First tests. Scandinavian Journal of Economics, 98(4), 463-484.

Ghufran, B., Awan, H. M., Khakwani, A. K., \& Qureshi, M. A. (2016). What causes stock market volatility in Pakistan? Evidence from the field. Available at: https://doi.org/10.1155/2016/3698297

Girton, L., \& Roper, D. (1977). A monetary model of exchange market pressure applied to the postwar Canadian experience. American Economic Review, 67(4), 537-48.

Government of Pakistan. (1996, 1999, 2007, 2009). Pakistan Economic Survey. Economic Advisor's Wing, Ministry of Finance, Islamabad.

Hakkio, C. S., \& Keeton, W. R. (2009). Financial stress: What is it, how can it be measured, and why does it matter? Economic Review, 94(2), 5-50.

ICRG: The International Country Risk Guide. (2017). The PRS, Inc., New York.

Illing, M., \& Liu, Y. (2006). Measuring financial stress in a developed country: An application to Canada. Journal of Financial Stability, 2(3), 243-265.

IMF: International Monetary Fund. (2004). Pakistan: Financial system stability assessment. IMF Country Report No. 04/215, Washington D.C.

Laevene, L., \& Valenica, F. (2013). Systematic banking crises database. IMF Economic Review, 61(2), 225-270.

Lo Duca, M., \& Peltonen, T. A. (2011). Macro-financial vulnerabilities and future financial stress. ECB Working Paper Series No 1311, European Central Bank, Frankfurt.

Mahmood, A., \& Hussain, S. Z. (2016). Measure of financial market stress for Pakistan, SBP Research Bulletin, 12(1), 43-51.

Makrwat, T., Kole, E., \& Dijk, D. (2009). Contagion as a domino effect in global stock markets. Journal of Banking and Finance, 33(11), 1996-2012.

Mei, J., \& Guo, L. (2004). Political uncertainty, financial crises and market volatility. European Financial Management, 10(4), 639-657.

Misina, M., \& Tkacz, G. (2009). Credit, asset prices, and financial stress. International Journal of Central Banking, 5(4), 95-122.

Park, C-Y., \& Mercado Jr, R. V. (2014). Determinants of financial stress in emerging market economies. Journal of Banking and Finance, 45(8), 199-224. 
Poonpatpibul, C., Tan, A., Liu Xinyi, S., \& Cho, E. (2018). Assessing Financial Stress in China, Japan, Korea and ASEAN-5 Economies. The ASEAN+3 Macroeconomic Research Office Working Paper (18-2).

Sandahl, J. F., Holmfeldt, M., Ryden, A., \& Stromqvist, M. (2011). An index of financial stress for Sweden. Sveriges Riks Bank Economic Review, 2, 49-67.

SBP: State Bank of Pakistan. (2000). Financial Sector Assessment, 1990-2000, Karachi.

SBP: State Bank of Pakistan. (1999-2000, 2007, 2009, 2010, 2015, 2016). Financial Stability Review, Karachi.

Titman, S., Kewon, A. J., \& Martin, J. D. (2011). Financial mangement: Principals and application (11 ${ }^{\text {th }}$ ed). Boston, MA: Pearson Addison-Wesley

Turner, P. (2007). Are banking systems in East Asia stronger? Asian Economic Policy Review, 2(1), 75-95.

Waszkiewicz, G. (2015). Political risk and national debt markets in advanced economies. Proceedings of FIKUSZ'15, Obuda University, Budapest, 263-275.

Waszkiewicz, G. (2017). Political risk in developed and developing economies. Journal of Economics and Management, 28(2), 112-132.

WB: The World Bank. (2000-2003). Financial Sector Assessment, Washington D.C. 
